Research Paper

\title{
ONC201 selectively induces apoptosis in cutaneous T-cell lymphoma cells via activating pro-apoptotic integrated stress response and inactivating JAK/STAT and NF-KB pathways
}

\author{
Xiao $\mathrm{Ni}^{1}$, Xiang Zhang ${ }^{1}$, Cheng-Hui Hu${ }^{1}$, Timothy Langridge ${ }^{1}$, Rohinton S. Tarapore ${ }^{2}$, \\ Joshua E. Allen ${ }^{2}$, Wolfgang Oster ${ }^{2}$ and Madeleine Duvic ${ }^{1}$ \\ ${ }^{1}$ Department of Dermatology, The University of Texas MD Anderson Cancer Center, Houston, TX, USA \\ ${ }^{2}$ Oncoceutics, Inc., Philadelphia, PA, USA \\ Correspondence to: Xiao Ni, email: xiaoni@mdanderson.org \\ Keywords: NHL, ONC201, TIC10, TRAIL, cancer \\ Received: December 22, $2016 \quad$ Accepted: May 22, $2017 \quad$ Published: June 27, 2017 \\ Copyright: $\mathrm{Ni}$ et al. This is an open-access article distributed under the terms of the Creative Commons Attribution License 3.0 \\ (CC BY 3.0), which permits unrestricted use, distribution, and reproduction in any medium, provided the original author and source \\ are credited.
}

\section{ABSTRACT}

Cutaneous T-cell lymphomas (CTCLs) are extremely symptomatic and still incurable, and more effective and less toxic therapies are urgently needed. ONC201, an imipridone compound, has shown efficacy in pre-clinical studies in multiple advanced cancers. This study was to evaluate the anti-tumor activity of ONC201 on CTCL cells. The effect of ONC201 on the cell growth and apoptosis were evaluated in CTCL cell lines $(n=8)$ and primary CD4+ malignant T cells isolated from CTCL patients $(n=5)$. ONC201 showed a time-dependent cell growth inhibition in all treated cell

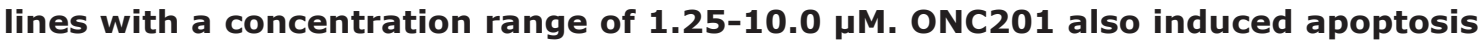
in tested cells with a narrow concentration range of 2.5-10.0 $\mu \mathrm{M}$, evidenced by increased Annexin $\mathbf{V}^{+}$cells, accompanied by accumulated sub-G1 portions. ONC201 only induced apoptosis in $\mathrm{CD}^{+}$malignant $\mathrm{T}$ cells, not in normal $\mathrm{CD4}^{+} \mathrm{T}$ cells. The activating transcription factor 4 (ATF4), a hallmark of integrated stress response, was upregulated in response to ONC201 whereas Akt was downregulated. In addition, molecules in JAK/STAT and NF-KB pathways, as well as IL-32 $\beta$, were downregulated following ONC201 treatment. Thus, ONC201 exerts a potent and selective anti-tumor effect on CTCL cells. Its efficacy may involve activating integrated stress response through ATF4 and inactivating JAK/STAT and NF-KB pathways.

\section{INTRODUCTION}

Cutaneous T-cell lymphomas (CTCLs) are a heterogeneous group of extranodal non-Hodgkin's lymphomas. They are characterized by skin-homing malignant clonal T-lymphocytes. Mycosis fungoides (MF) and Sézary syndrome (SS) are two most common forms of CTCLs. MF can be chronic and indolent or progress to involve the blood, lymph nodes, and other internal organs [1]. SS is characterized by erythroderma and the presence of Sézary cells in the blood, which are immunophenotypically $\mathrm{CD} 4^{+} \mathrm{CD} 26^{-}$or $\mathrm{CD} 4^{+} \mathrm{CD} 7^{-} \mathrm{T}$ cells [2]. There are currently limited treatment options for patients with advanced CTCL, and approved therapies have response rates of around 30\%
$[3,4]$. The currently available agents are expensive and have toxicity including immunosuppression predisposing to infections. Disease recurrence and therapy resistance are common. Thus, there remains an unmet need for novel and safe therapies to treat CTCL.

ONC201 or TIC10 is a chemical compound referred to as 7-benzyl-4-(2-methylbenzyl)-1,2,6,7,8,9hexahydroimidazo[1,2-a]pyrido[3,4-e]pyrimidin-5(4H)one. It is the first-in-class member of the imipridone class of anti-cancer compounds and a highly selective $G$ protein-coupled receptor (GPCR) antagonist [5]. This oral small molecule is currently in clinical trials for advanced cancers [5]. Although it is known that ONC201 induces apoptosis in refractory tumor cells in a p53-independent 
manner, its other potential mechanisms of action that lead to anti-tumor activity are still under investigation $[6,7]$. A prior report on the mechanism (s) of action of ONC201 in preclinical solid tumor models implicated a late stage inactivation of Akt and ERK leading to Foxo3a-mediated induction of TRAIL and its pro-apoptotic receptor DR5 [7]. Recent studies have also implicated the integrated stress response (ISR) as an early stage mechanism of ONC201 that may lead to its previously observed downstream anti-cancer effects [8]. ONC201 activates the integrated stress response that attenuates protein translation and upregulates activating transcription factor 4 (ATF4), which causes induction of genes that lead to apoptosis.

The signal transducers and activators of transcription (STAT) family members, such as STAT3, are commonly activated in CTCL [9]. STATs can be phosphorylated by one of four upstream Janus kinases (JAKs) following cytokine stimulation. Upon nuclear translocation, phosphorylated STAT3 (pSTAT3) directly regulates expression of key target genes, including cell cycle genes (Cyclin D and myc), regulators of apoptosis (BCL-2/ BAX), cytokines (e.g. IL-5 and IL-13), and suppressors of cytokine signaling (SOCS3) that work together to promote carcinogenesis [10-13]. Constitutive activation of STAT1, STAT3 and STAT5 has been observed in both early and late stages of CTCL [9]. In addition, STAT3 indirectly regulates gene expression by inducing DNA methyltransferase 1 (DNMT1), thereby promoting the epigenetic silencing of tumor suppressor genes [14]. Thus, constitutively active STAT3 can increase survival and resistance to apoptosis in malignant T cells in CTCL.

Meanwhile, the dysregulated nuclear factor $\kappa \mathrm{B}(\mathrm{NF}-$ $\kappa \mathrm{B})$ pathway has also been implicated in CTCL. NF- $\kappa \mathrm{B}$ is a key transcriptional regulator of cytokines controlling cell survival, differentiation, proliferation, angiogenesis, metastasis, and inflammatory responses [15]. In early stages of CTCL, autocrine tumor necrosis factor alpha (TNF $\alpha$ ) expression increases NF- $\kappa$ B activation that leads to cellular proliferation and resistance to apoptosis $[16$, 17]. In addition to TNF $\alpha$, the epidermis in patients with CTCL contains increased levels of NF- $\kappa \mathrm{B}$-dependent proinflammatory cytokines IL-1 $\beta$, IL-8, IL-17, and IL-32 suggesting a role for these cytokines in the pathogenesis of CTCL [18-21]. Increased NF- $\kappa B$ activity in CTCL is also responsible for increased resistance to apoptosis by up-regulating the anti-apoptotic cellular inhibitor of apoptosis proteins (cIAP) and BCL-2 [22]. Thus, NF-кB plays a key role in CTCL by promoting inflammation and by inhibiting apoptosis.

It is reported that STAT3 and NF- $\kappa \mathrm{B}$ often cooperate to promote the development and progression of solid cancers [23]. Both NF- $\kappa \mathrm{B}$ and STAT3 are rapidly activated in response to various stimuli including stresses and cytokines, although they are regulated by different signaling mechanisms. Once activated, NF- $\kappa$ B and STAT3 can independently and/or synergistically control the expression of anti-apoptotic, pro-proliferative and immune response genes [23].

Based on the preclinical profile of ONC201 and the need for novel, safe and effective therapies for CTCL, this study was undertaken to evaluate the effect of ONC201 on CTCL cells and to understand its mechanism of action.

\section{RESULTS}

\section{ONC201 inhibits cell growth in CTCL cell lines}

We first assessed the anti-proliferative effect of ONC201 on CTCL cells by the CellTiter Cell Proliferation Assay (MTS). Eight CTCL cell lines were treated with ONC201 at $0,1.25 \mu \mathrm{M}, 2.5 \mu \mathrm{M}, 5.0 \mu \mathrm{M}$, and $10.0 \mu \mathrm{M}$, respectively, over 48 hours ( $48 \mathrm{hrs}$ ), 72 hours ( $72 \mathrm{hrs}$ ), and 96 hours (96 hrs). As shown in Figure 1, the cell growth was inhibited in all 8 cell lines, but with different sensitivities. HH cells were the most sensitive with the cell growth inhibited from $1.25 \mu \mathrm{M}$ of ONC201 treatment at $48 \mathrm{hrs}(42.4 \%)$, to a maximum at $96 \mathrm{hrs}(62.2 \%, \mathrm{p}<0.05)$. The growth of MJ cells was inhibited at $2.5 \mu \mathrm{M}$, sustained at $5.0 \mu \mathrm{M}$ or $10 \mu \mathrm{M}$, and reached a maximum at $96 \mathrm{hrs}$. Interestingly, the cell growth inhibition in 3 other cell lines (Mac2A, MyLA, and PB2S) was not significantly enhanced when ONC201 doses were increased from $5.0 \mu \mathrm{M}$ to $10.0 \mu \mathrm{M}$. H9 cells were least sensitive, as the inhibition was only seen at $10 \mu \mathrm{M}$ of ONC201. These results suggest that $\mathrm{ONC} 201$ has an anti-proliferative effect on CTCL cells, and it inhibits cell growth within a narrow concentration range from $1.25 \mu \mathrm{M}$ to $10.0 \mu \mathrm{M}$ in a time-dependent manner.

\section{ONC201 induces apoptosis in CTCL cell lines}

We next determined the pro-apoptotic effect of ONC201 on 8 CTCL cell lines treated with similar doses of ONC201 and at similar time points. The apoptotic cells were analyzed by flow cytometry using Annexin $\mathrm{V} /$ propidium iodide (PI) staining. ONC201 was able to induce apoptosis in all 8 cell lines at different doses (Figure 2). Again, $\mathrm{HH}$ cells were the most sensitive to ONC201, at concentrations starting at $2.5 \mu \mathrm{M}$ over a longer 72-hour period. Apoptosis occurred in $47.9 \%$ of HH cells at $2.5 \mu \mathrm{M}$ of ONC201 over 72 hours of treatment, which was increased by 7.6 -fold in comparison to $1.25 \mu \mathrm{M}$ at $72 \mathrm{hrs}(6.3 \%)$, and was also doubled in comparison to $2.5 \mu \mathrm{M}$ for a 48 -hour treatment $(20.3 \%, \mathrm{p}<0.05)$. Hut78 and $\mathrm{MJ}$ cells had increased numbers of apoptotic cells at $2.5 \mu \mathrm{M}$, for a 96-hour of treatment, with low levels at early time points. ONC201 also induced apoptosis in 4 other cell lines (H9, Mac2A, MyLA, and SeAx cells) at a higher dose of $5.0 \mu \mathrm{M}$ over a 96 -hour of treatment. Compared to other cells, PB2S cells were the least sensitive to ONC201, and the induction of apoptosis was only observed at 10 

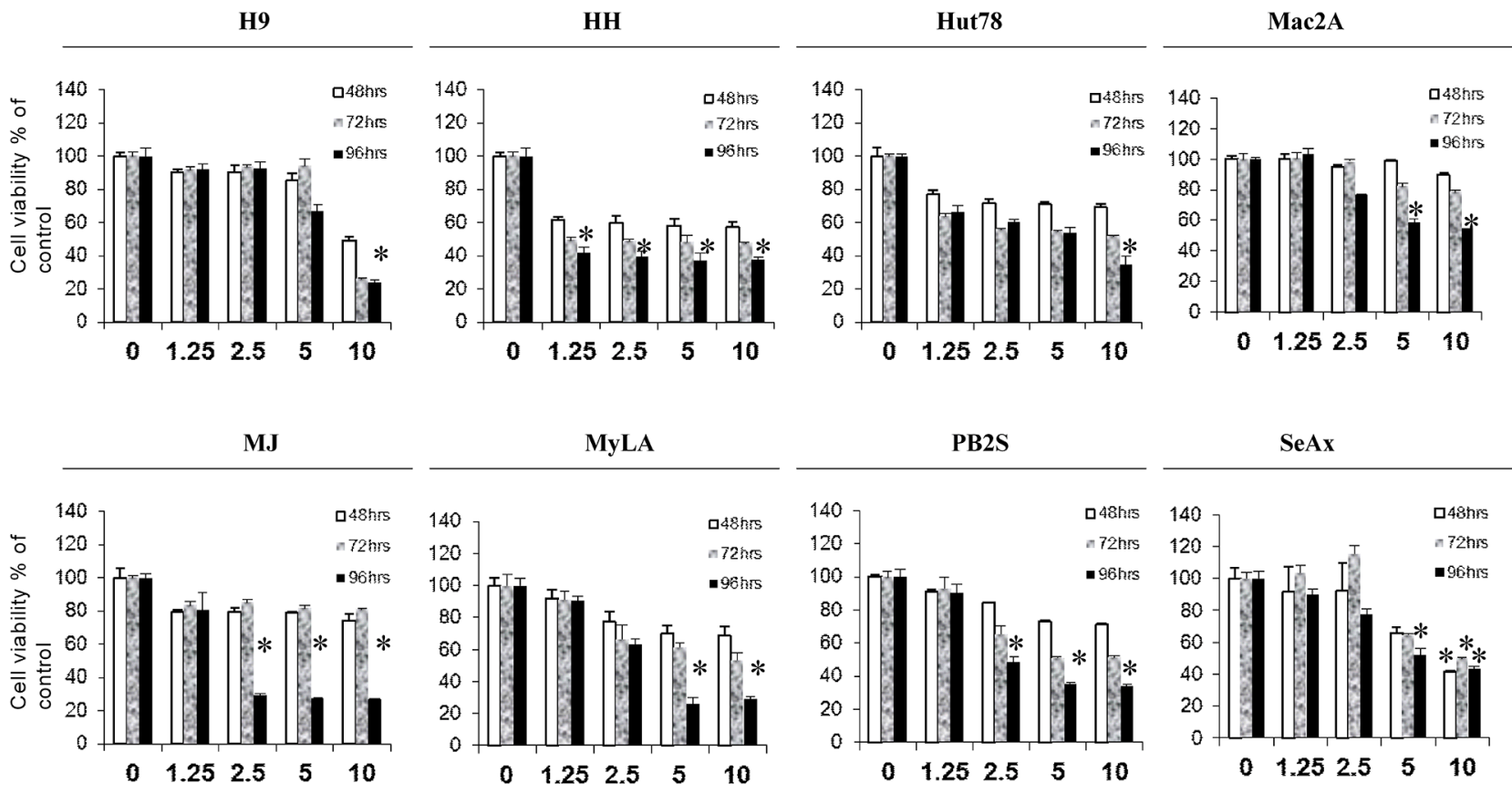

Concentrations of ONC201 $(\mu \mathrm{M})$

Figure 1: ONC201 inhibits cell growth in CTCL cell lines. H9, HH, Hut78, Mac2A, MJ, MyLa, PB2S, and SeAx cells were cultured in 96 -well culture plates $\left(5 \times 10^{4 /}\right.$ well) with or without $1.25,2.5,5.0$, and $10.0 \mu \mathrm{M}$ of ONC201 for 48,72 , and 96 hrs, respectively. Cell viability was determined using CellTiter 96® Aqueous One Solution Cell Proliferation Assay (MTS). Data for 8 cell lines were presented with different doses at 3 time points (mean $\pm \mathrm{SD}$ of triplicate determinations). ${ }^{*}$ significant difference, $\mathrm{p}<0.05$.
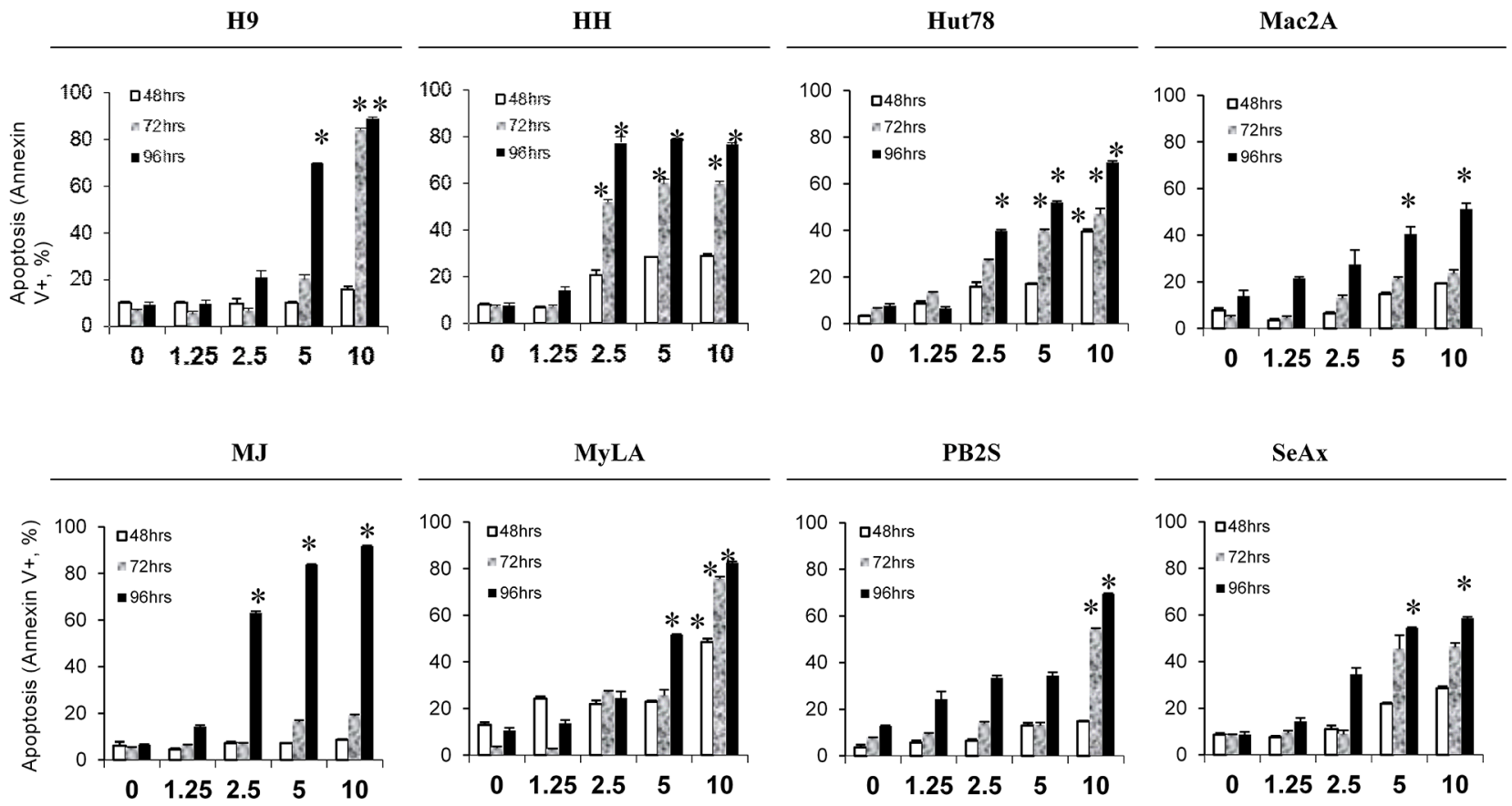

Concentrations of ONC201 $(\mu \mathrm{M})$

Figure 2: ONC201 induces apoptosis in CTCL cell lines. H9, HH, Hut78, Mac2A, MJ, MyLa, PB2S, and SeAx cells (5×10 $5 / \mathrm{ml})$ were treated with or without $1.25,2.5,5.0$, and $10.0 \mu \mathrm{M}$ ofONC201 for 48, 72, and 96 hrs. Apoptotic cells were assessed by flow cytometry using the Annexin V-FITC Detection Kit. Data were presented as the percentage of Annexin $\mathrm{V}^{+}$cells for all 8 cell lines with different doses at 3 time points (mean $\pm \mathrm{SD}$ of triplicate determinations). *significant difference, $\mathrm{p}<0.05$. 
$\mu \mathrm{M}$. These results suggest that ONC201 induces CTCL cell apoptosis within a very narrow concentration range from $2.5 \mu \mathrm{M}$ to $10.0 \mu \mathrm{M}$ in a time-dependent manner.

We next examined the effect of ONC201 on cellcycle sub-G1 and/or apoptosis by flow cytometry in 3 cell lines: SS-derived HH, Hut78 cells, and MF-derived MJ cell lines. As shown in Figure 3A\&3B, sub-G1 populations were increased in all 3 cell lines in a time- and dose-dependent manner. Significant increases of sub-G1 populations were seen from $2.5 \mu \mathrm{M}$ over $96 \mathrm{hrs}$. HH cells showed the highest sensitivity, followed by Hut78 and MJ cells, consistent with our results from Annexin V/PI staining suggesting that the cells are undergoing apoptosis.

\section{ONC201 selectively induces apoptosis in primary Sézary cells}

One reason that ONC201 was selected as a lead compound for clinical development is its lack of toxicity in normal cells [5]. We next examined the pro-apoptotic effects of ONC201 on primary Sézary cells in comparison to normal $\mathrm{CD}^{+} \mathrm{T}$ cells from healthy donors. Primary
$\mathrm{CD}^{+}$malignant $\mathrm{T}$ cells were isolated from the peripheral blood of 5 patients with MF/SS who had $>60 \%$ circulating $\mathrm{CD}^{+} \mathrm{CD} 26^{-} \mathrm{T}$ cells of total lymphocytes (Table 1, Patient \#1 - \#5). Cells were incubated with or without ONC201 at concentrations ranging from 1.25 to $10 \mu \mathrm{M}$ for $48 \mathrm{hrs}$ and $72 \mathrm{hrs}$. The apoptotic cells were then assessed by flow cytometry using Annexin V/PI staining. Similar to $\mathrm{HH}$ and Hut78 cells, apoptotic $\mathrm{CD} 4^{+}$malignant $\mathrm{T}$ cells were dramatically increased at $2.5 \mu \mathrm{M}(19.4 \%$ at $48 \mathrm{hrs}$; $33.7 \%$ at $72 \mathrm{hrs}, \mathrm{n}=5)$, in comparison to $1.25 \mu \mathrm{M}(5.8 \%$ at $48 \mathrm{hrs} ; 4.1 .0 \%$ at $72 \mathrm{hrs}, \mathrm{n}=5$ ). There was no significant enhancement when ONC201 doses were increased from $5.0 \mu \mathrm{M}$ to $10.0 \mu \mathrm{M}$ (Figure $4 \mathrm{~A}$ ). In contrast, normal CD4 ${ }^{+}$ $\mathrm{T}$ cells showed little response to ONC201, with an average apoptosis rate of $0.3 \%$ at $1.25 \mu \mathrm{M}$ and $2.0 \%$ at $10 \mu \mathrm{M}$ after a 48 -hour treatment, and $0.4 \%$ to $2.4 \%$ after a 72 -hour treatment $(\mathrm{n}=6)$. Representative flow plots for Annexin $\mathrm{V}^{+}$apoptotic $\mathrm{CD} 4^{+} \mathrm{T}$ cells from a healthy donor (left) and Patient \#5 (right) are presented in Figure 4B. As shown in Table 1, the number of $\mathrm{CD} 4^{+} \mathrm{CD} 26^{-}$malignant $\mathrm{T}$ cells in the blood of Patient \#5 was 3332/ $\mu \mathrm{L}$ representing $79.1 \%$ of all lymphocytes in the blood. Our results suggest that

A.

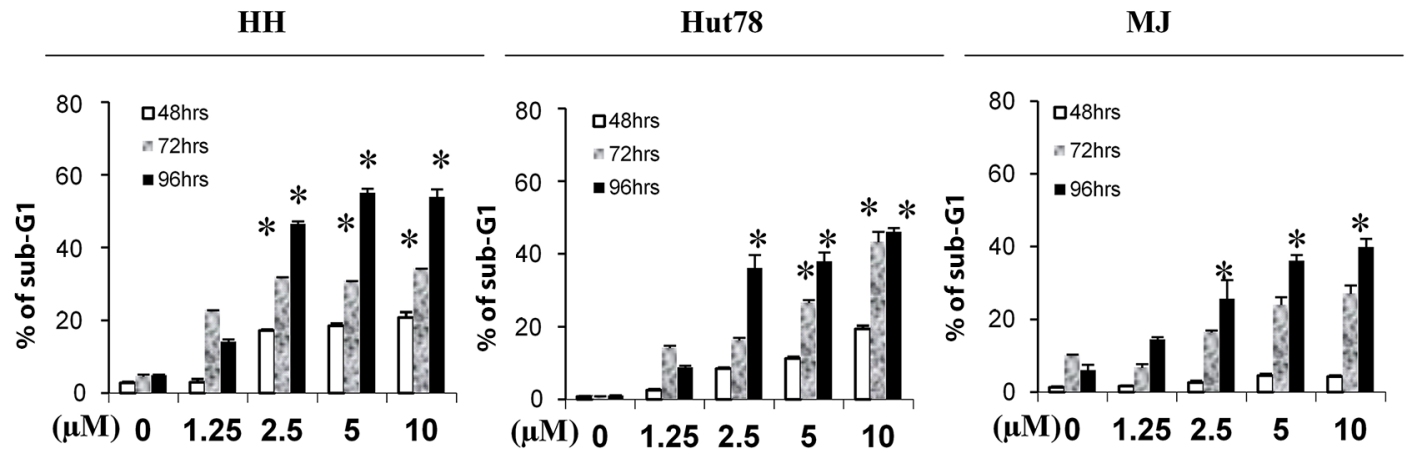

B.
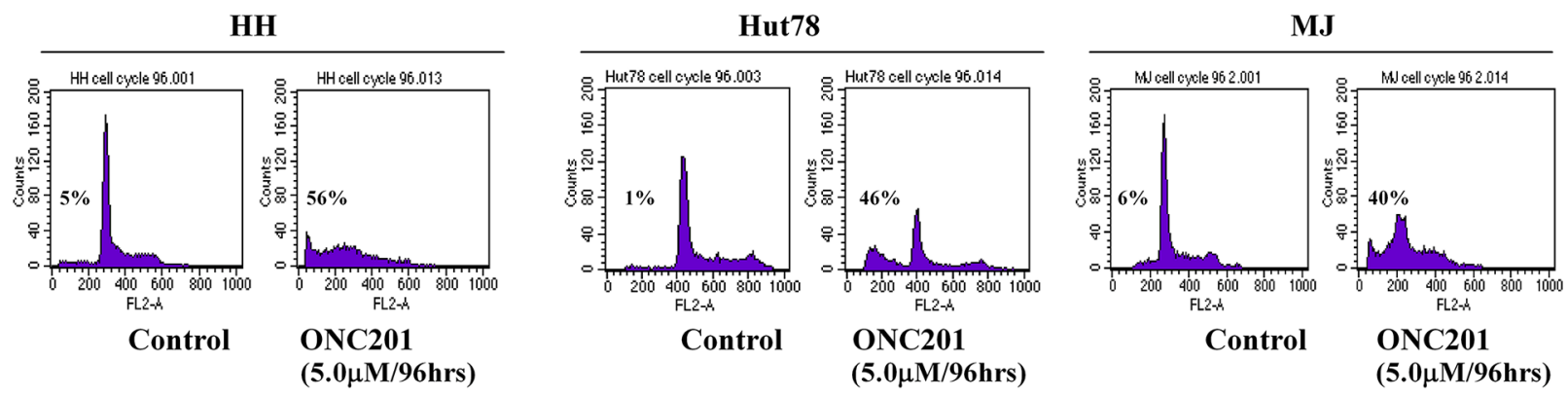

Figure 3: ONC201 induces accumulation of sub-G1 portions in CTCL cell lines. HH, Hut78 and MJ cells $\left(5 \times 10^{5}\right)$ were treated with or without $1.25,2.5,5.0$, and $10.0 \mu \mathrm{M}$ of ONC201 for 48,72 , and $96 \mathrm{hrs}$. Cells were stained with PI, and sub-G1 distributions were determined by flow cytometry. (A) The percentages of sub-G1 portions for HH, Hut78, and MJ cells were presented with different doses at 3 time points (mean $\pm \mathrm{SD}$ of triplicate determinations). *significant difference, $\mathrm{p}<0.05$. (B) Plots for representative paired cells with or without $5.0 \mu \mathrm{M}$ of ONC201 for 96 hrs were presented. The $\%$ of sub-G1portion in each plot was indicated. 
Table 1: Clinical demographics of patients with MF/SS

\begin{tabular}{|c|c|c|c|c|}
\hline Patient \# & Age/Gender* & Diagnosis** & $\begin{array}{c}\text { CD4 }^{+} \text {CD26- T-cells } \\
\text { of total lymphocytes }(\%)\end{array}$ & $\begin{array}{c}\text { Absolute CD4 }{ }^{+} \mathrm{CD}^{-}{ }^{-} \\
\text {T-cells }(/ \mu \mathrm{L})\end{array}$ \\
\hline 1 & $80 / \mathrm{M}$ & SS & 91.6 & 2800 \\
\hline 2 & $72 / \mathrm{M}$ & $\mathrm{MF}$ & 60.5 & 708 \\
\hline 3 & $66 / \mathrm{M}$ & MF & 66.9 & 2295 \\
\hline 4 & $62 / \mathrm{F}$ & SS & 67.5 & 2588 \\
\hline 5 & $63 / \mathrm{F}$ & SS & 79.1 & 3332 \\
\hline 6 & $73 / \mathrm{F}$ & $\mathrm{MF} / \mathrm{SS}$ & 40.4 & 190 \\
\hline 7 & $79 / \mathrm{F}$ & $\mathrm{MF} / \mathrm{SS}$ & 94.0 & 6612 \\
\hline 8 & $59 / \mathrm{F}$ & $\mathrm{MF} / \mathrm{SS}$ & 82.6 & 13629 \\
\hline
\end{tabular}

*Gender: $\mathrm{M}$ - male, $\mathrm{F}$ - female; **Diagnosis: SS - Sézary syndrome, MF - mycosis fungoides

Table 2: Changes in mRNA levels of related molecules in 3 CTCL cell lines treated with ONC201

\begin{tabular}{|c|c|c|c|c|c|c|c|c|c|}
\hline \multirow[b]{2}{*}{ ONC201 for $72 \mathrm{~h}$} & \multicolumn{3}{|c|}{ HH } & \multicolumn{3}{|c|}{ MJ } & \multicolumn{3}{|c|}{ HuT78 } \\
\hline & $\mathbf{0} \mu \mathbf{M}$ & $1.25 \mu \mathrm{M}$ & $5.0 \mu \mathrm{M}$ & $\mathbf{0} \boldsymbol{\mu M}$ & $1.25 \mu \mathrm{M}$ & $5.0 \mu \mathrm{M}$ & $\mathbf{0} \mu \mathrm{M}$ & $1.25 \mu \mathrm{M}$ & $5.0 \mu \mathrm{M}$ \\
\hline eIF2S1 & 1.00 & 1.07 & 5.78 & 1.00 & 1.04 & 1.55 & 1.00 & 1.12 & 2.35 \\
\hline ATF4 & 1.00 & 1.78 & 11.80 & 1.00 & 1.23 & 2.17 & 1.00 & 1.26 & 2.08 \\
\hline AKT1 & 1.00 & 1.24 & 2.02 & 1.00 & 1.56 & 2.29 & 1.00 & 1.40 & 2.15 \\
\hline BAX & 1.00 & 1.41 & 6.81 & 1.00 & 1.43 & 2.69 & 1.00 & 0.85 & 1.69 \\
\hline JAK3 & 1.00 & 1.79 & 5.76 & 1.00 & 1.56 & 1.69 & 1.00 & 1.20 & 2.25 \\
\hline STAT1 & 1.00 & 2.56 & 7.07 & 1.00 & 0.96 & 0.75 & 1.00 & 1.49 & 1.35 \\
\hline STAT3 & 1.00 & 1.28 & 4.21 & 1.00 & 1.44 & 1.59 & 1.00 & 1.33 & 2.55 \\
\hline IRF7 & 1.00 & 2.16 & 15.93 & 1.00 & 1.02 & 2.52 & 1.00 & 0.82 & 1.57 \\
\hline NF-кB & 1.00 & 1.43 & 3.30 & 1.00 & 1.06 & 1.39 & 1.00 & 1.18 & 1.38 \\
\hline IL32 & 1.00 & 1.25 & 3.59 & 1.00 & 1.09 & 1.84 & 1.00 & 0.72 & 0.61 \\
\hline
\end{tabular}

ONC201 selectively induces apoptosis in primary Sézary cells but not in normal $\mathrm{CD} 4^{+} \mathrm{T}$ cells.

\section{ONC201 activates integrated stress response through ATF4 in CTCL cells}

The results above suggest a potent anti-tumor activity of ONC201 on CTCL cells, and we next investigated its mechanism(s) of action. Activation of the integrated stress response (ISR) induced by ONC201 has recently been implicated as the driver of its late downstream anti-tumor effects [5, 8, 24]. ISR activation often results in phosphorylation of eukaryotic initiation factor eIF2 $\alpha$,upregulation of certain transcription factors, such as activating transcription factor 4 (ATF4), an apical hallmark of the integrated stress response, and downregulation of the general protein synthesis [25]. In addition, ONC201-mediated Akt/ERK inactivation and TRAIL upregulation are implicated in colorectal cancer models [5]. We first assessed the protein expression of eIF $2 \alpha$, p-eIF $2 \alpha$, ATF4, Akt, and TRAIL by western blot in cells treated with or without 1.25 or $5.0 \mu \mathrm{M}$ of ONC201 for $72 \mathrm{hrs}$. As expected, ONC201 induced ATF4 protein expression at $5.0 \mu \mathrm{M}$ of ONC201 in 3 tested cell lines (Figure 5A) as well as PBMCs from $3 \mathrm{MF} / \mathrm{SS}$ patients (Figure 5B, Table 1, Patient \#6-8). However, the expression of total eIF $2 \alpha$ and p-eIF $2 \alpha$ proteins were unchanged or slightly down-regulated in 3 treated cell lines. Akt protein levels were decreased in Hut78 cells and in PBMCs from $3 \mathrm{MF} / \mathrm{SS}$ patients starting at $1.25 \mu \mathrm{M}$, and enhanced at 5.0 $\mu \mathrm{M}$. TRAIL protein expression was increased in $\mathrm{HH}$ and $\mathrm{MJ}$ cells at 1.25 and $5.0 \mu \mathrm{M}$ of ONC201 treatment. In further support of apoptosis induced by this pharmacological manipulation, a striking increase in BAX, another pro-apoptotic protein, and caspasemediated cleavage of poly (ADP-Ribose) polymerase (C-PARP) were documented following ONC201 treatment (Figure 5A\&5B). These results suggest that ONC201 
works on CTCL cells by activating ISR through inducing the expression of ATF4. Other mechanisms of action such as inactivation of Akt and induction of TRAIL, as previously reported in solid tumors [7], are also involved in mechanisms of action of ONC201 in CTCL cells. But, the induction of ATF4 in ONC201-treated CTCL cells may be independent of phosphorylation of $\operatorname{eIF} 2 \alpha$.

\section{ONC201 inactivates the JAK/STAT pathway in CTCL cells}

Constitutive activation of the JAK/STAT pathway has been demonstrated in CTCL, and is critical for cell proliferation and survival $[9,26]$. The robust activity of ONC201 on CTCL cell growth and apoptosis induction suggest that ONC201 may affect the JAK/STAT pathway in CTCL cells. Recent studies have revealed that STAT3 is negatively regulated in response to TRAIL [27]. Expression of JAK3, pJAK3, STAT3, pSTAT3, and pSTAT1 protein levels were examined by western blot in cells treated with or without ONC201. Levels

A.

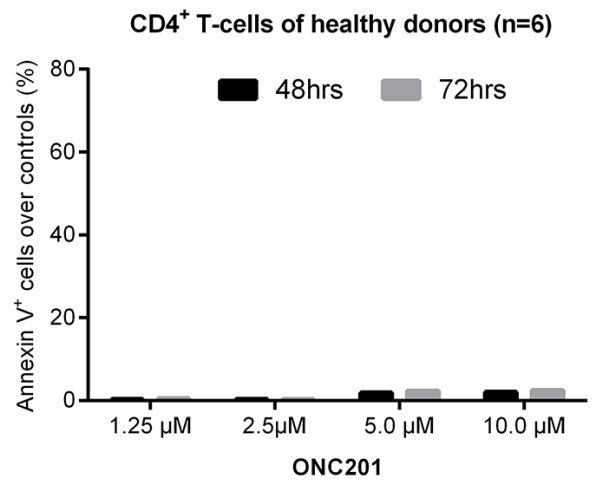

B.

CD4+ cells from a healthy donor
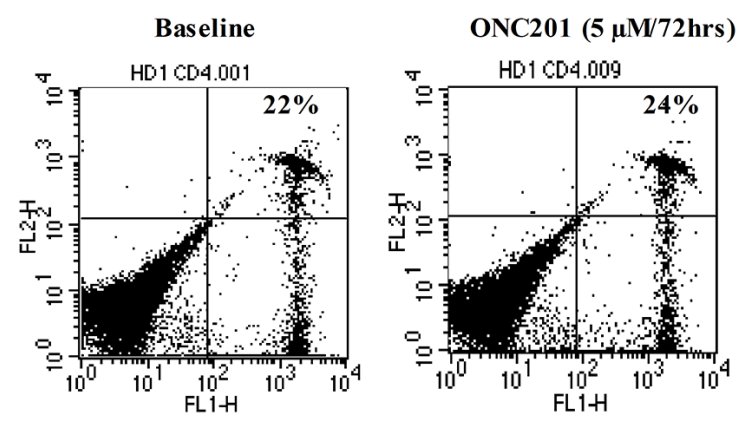

of these proteins were decreased in ONC201-treated $\mathrm{HH}$ and Hut78 cells (Figure 6A). Their levels were also dramatically decreased in PBMCs treated with $5.0 \mu \mathrm{M}$ of ONC201 (Figure 6B). Surprisingly, pJAK3 protein was undetectable in PBMCs from MF/SS patients, but was present in 3 cell lines. Of note, MJ cells showed a reduction of pSTAT 1 protein but not STAT3 and pSTAT3 proteins as shown in Figure 6A.

In order to further explore the connection between integrated stress responses and a decreased JAK/STAT pathway, we assessed another molecule, interferon regulatory factor 7 (IRF7). ATF4 has been identified as a negative regulator of IRF7 and inhibits the transcription and phosphorylation of IRF7 [28]. As shown in Figure 6A\&6B, HH and Hut78 cells and PBMCs from $3 \mathrm{MF} / \mathrm{SS}$ patients had decreased expression of IRF7 after ONC201 treatment, but not MJ cells. The expression of p-IRF7 expression was decreased in all 3 tested cell lines and PBMCs from $2 \mathrm{MF} / \mathrm{SS}$ patients (\#7 and \#8).

Our results support that ONC201 inactivates the JAK/STAT pathway and downregulates IRF7 in both

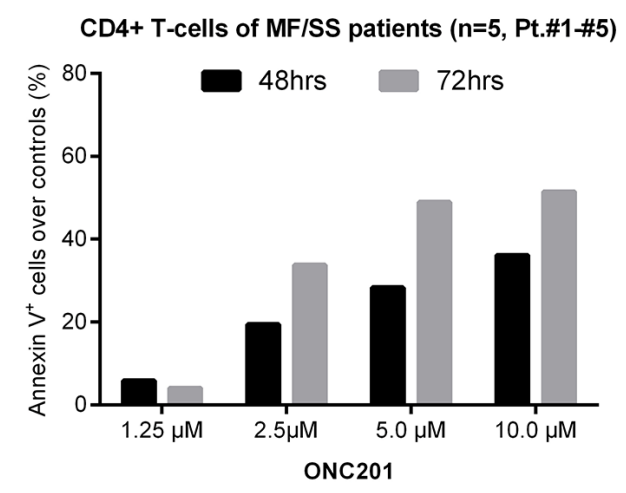

Figure 4: ONC201 selectively induces apoptosis in $\mathbf{C D}^{+}$malignant $\mathbf{T}$ cells. $\mathrm{CD}^{+} \mathrm{T}$ cells $\left(5 \times 10^{5}\right)$ from $\mathrm{MF} / \mathrm{SS}$ patients and healthy donors were treated with or without $1.25,2.5,5.0$, and $10.0 \mu \mathrm{M}$ of ONC201 for 48 and 72 hrs. Apoptotic cells were assessed by flow cytometry using the Annexin V-FITC Detection Kit. (A) The percentages of Annexin $\mathrm{V}^{+}$cells were presented for normal CD4 $4^{+} \mathrm{T}$ cells (mean, $\mathrm{n}=6$ ) and malignant $\mathrm{CD} 4^{+} \mathrm{T}$ cells (mean, $\mathrm{n}=5$; Patient $\# 1$ - \#5) with different doses at two time points. (B) Dot plots for representative $\mathrm{CD}^{+} \mathrm{T}$ cells from a healthy donor (left) and Patient $\# 5$ with or without $5.0 \mu \mathrm{M}$ of ONC201 for 72 hrs were presented. 
A.

ONC201 $(\mu \mathrm{M})$

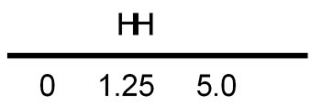

\begin{tabular}{lll}
\multicolumn{3}{c}{ M } \\
\hline 0 & 1.25 & 5.0
\end{tabular}

\begin{tabular}{lll}
\multicolumn{3}{c}{ Hut78 } \\
\hline 0 & 1.25 & 5.0
\end{tabular}

elF $2 \alpha$

p-elF2 $\alpha$

ATF4

Akt
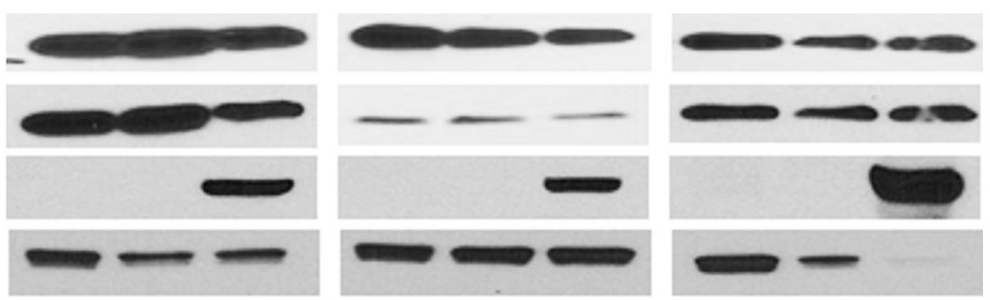

TRAIL
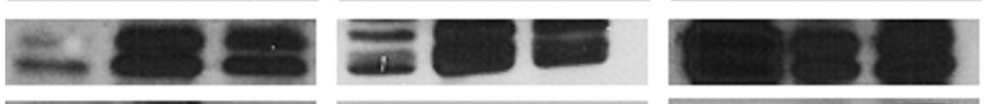

BAX

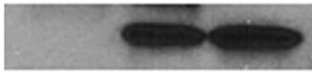

C-PARP
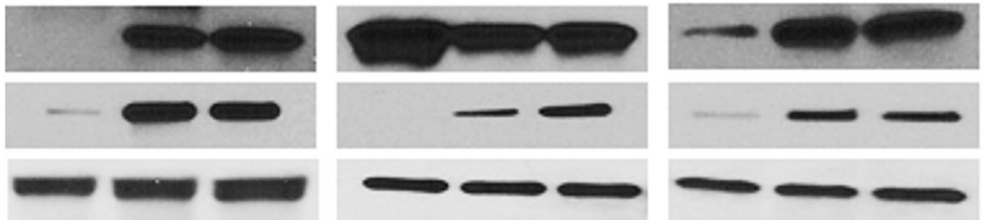

$\beta$-actin

0
0
$0.25 \mu \mathrm{M}$
$0.0 \mathrm{M}$
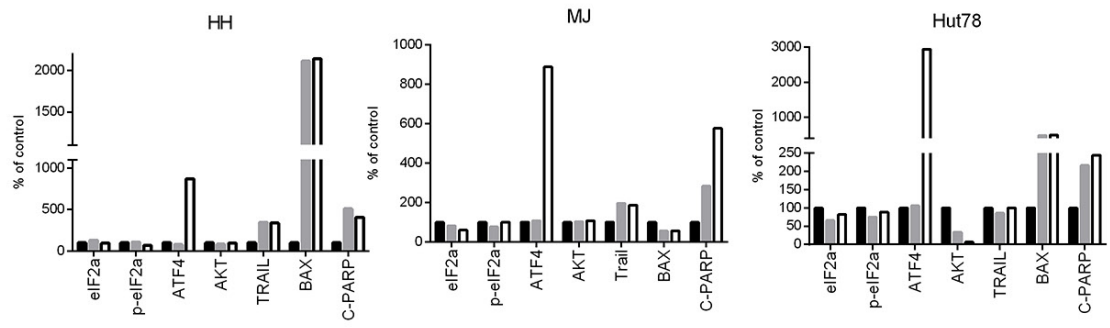

B.
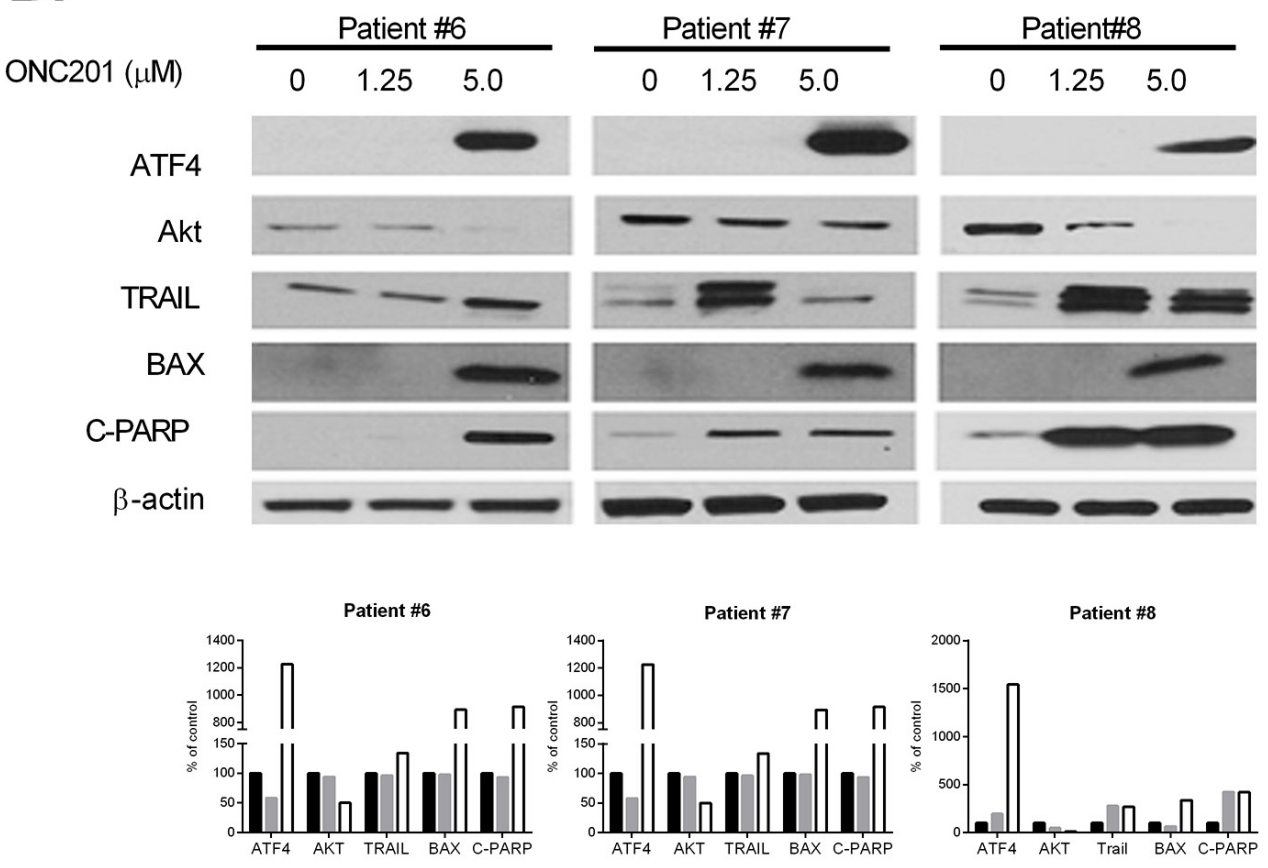

Figure 5: ONC201 upregulates ATF4, downregulates Akt, and induces TRAIL in CTCL cell lines and primary Sézary cells. HH, Hut78, and MJ cells (A), and PBMCs from $3 \mathrm{MF} / \mathrm{SS}$ patients (Patient \#6 - \#8) (B) were treated with $(1.25$ or $5.0 \mu \mathrm{M})$ or without ONC201 for 72 hrs. The protein expression of eIF2 $\alpha$, p-eIF2 $\alpha$, ATF4, Akt, TRAIL, BAX, and C-PARP were assessed by western blot. The protein level of $\beta$-actin served as housekeeping gene control. All protein levels were semi-quantified using ImageJ system (NIH), and the levels in treated cells were compared with untreated control cells which were considered as $100 \%$. 
A.
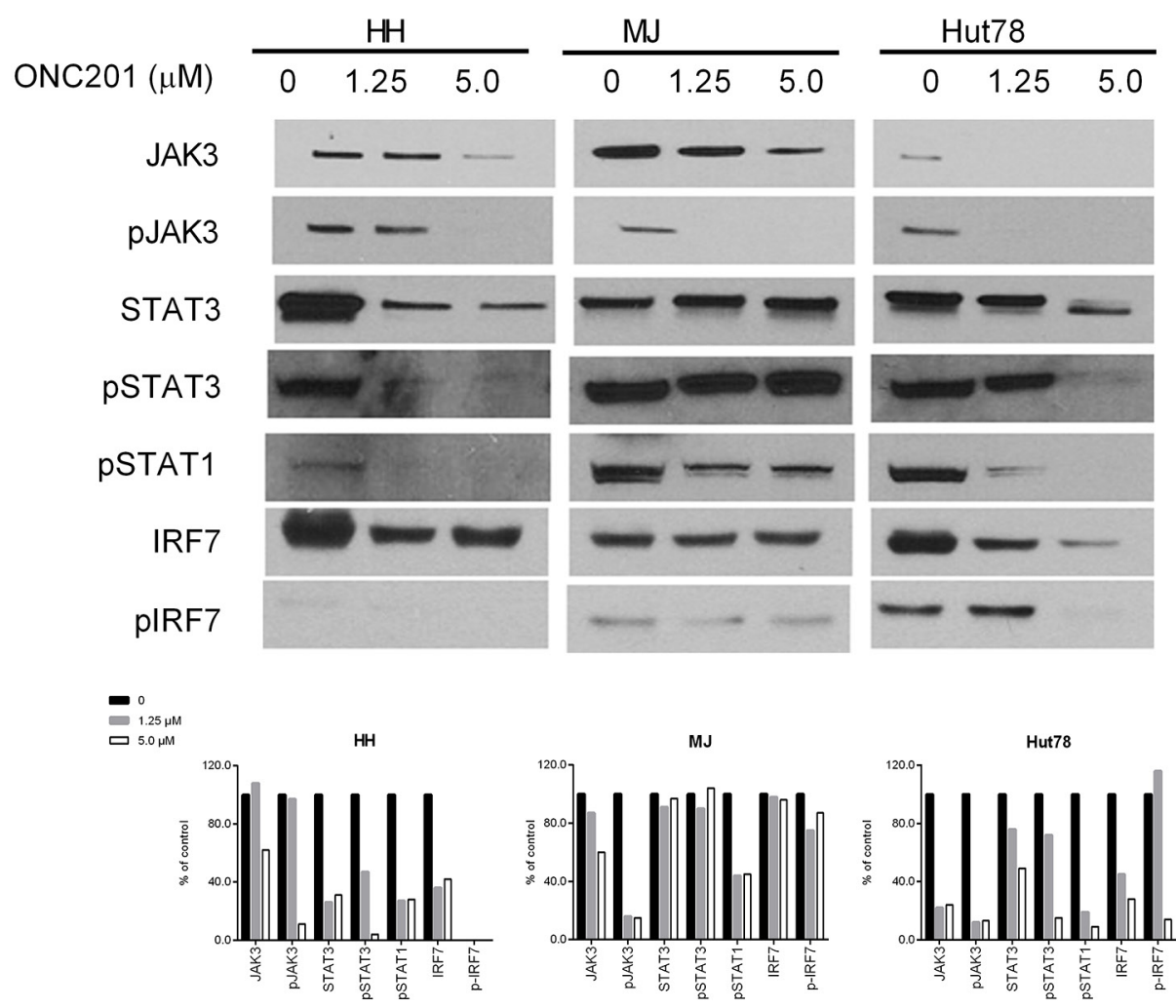

B.
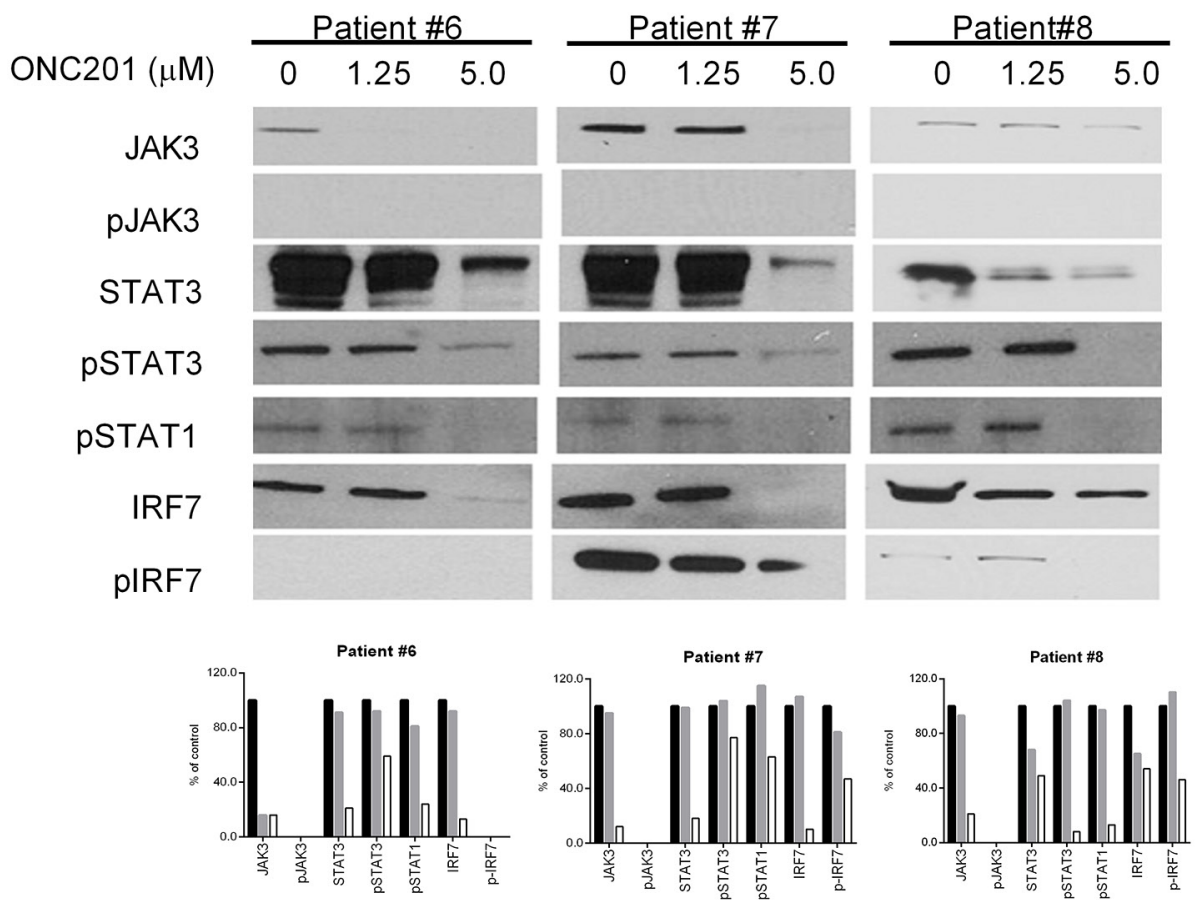

Figure 6: ONC201 downregulates JAK/STAT in CTCL cell lines and primary Sézary cells. HH, Hut78, and MJ cells (A), and PBMCs from 3 MF/SS patients (Patient \#6 - \#8) (B) were treated with (1.25 or $5.0 \mu \mathrm{M})$ or without ONC201 for 72 hrs. The protein expression of JAK3, pJAK3, STAT3, pSTAT3, pSTAT1, IRF7, and pIRF7 were assessed by western blot. Protein levels were semiquantified as above, and the protein levels in treated cells were compared with untreated control cells which were considered as $100 \%$. 
CTCL cell lines and primary Sézary cells. IRF7 may be a connection molecule between integrated stress response and the downstream Jak3/STAT3 signaling axis.

\section{ONC201 downregulates the NF- $\kappa \mathrm{B}$ pathway in CTCL cells}

It is well documented that constitutive activation of the NF- $\kappa \mathrm{B}$ pathway plays a role in the development of CTCL and is related to cell resistance to apoptosis [26]. Therefore, we also analyzed protein expression of NF- $\kappa \mathrm{B}$ family members (p65, RelB, C-Rel and p105) by western blot in ONC201 treated cells. ONC201 significantly decreased the protein levels of all four NF- $\kappa \mathrm{B}$ members in three CTCL lines (Figure 7A) and in PBMCs from 3 $\mathrm{MF} / \mathrm{SS}$ patients (Figure $7 \mathrm{~B}$ ) at $5.0 \mu \mathrm{M}$, compared to 1.25 $\mu \mathrm{M}$ and empty controls. Our results suggest that ONC201 inactivates not only the JAK/STAT pathway, but also the NK $\kappa$ B pathway in CTCL cells. These effects may underlie the therapeutic effects of ONC201 on CTCL cells.

\section{ONC201 downregulates IL-32 $\beta$ expression in CTCL cells}

IL-32 is known as a pro-inflammatory cytokine that is likely involved in the lymphomagenesis of CTCL [29]. We recently reported that both IL-32 transcripts and cellular IL-32 $\beta$ protein were highly increased in both CTCL cell lines and malignant T cells from MF/SS patients [30]. Of interest, NK- $\kappa \mathrm{B}, \mathrm{NF}-\kappa \mathrm{B} 1$, and STAT3 are key transcription factors regulating IL-32 gene expression. We found decreased levels of IL-32 $\beta$ protein in all ONC201-treated cells, in parallel with downregulation of $\mathrm{NK}-\kappa \mathrm{B}$ proteins as indicated in Figure 7A\&7B.

\section{Down-regulation of JAK/STAT and NF-кB pathways is not transcriptionally mediated}

We next addressed whether the changes in protein expression after ONC201 treatment are a consequence of a transcriptional regulation or not. The mRNA levels of most aforesaid molecules in 3 CTCL cell lines with or without ONC201 at 72 hrs were examined by real-time PCR. As summarized in Table 2, only IL-32 in Hut78 cells and STAT1 in MJ cells were slightly reduced after treatment with ONC201 for 72 hours. The mRNA levels of the rest of the molecules increased slightly in treated cell lines, especially in $\mathrm{HH}$ cells with a concentration at $5.0 \mu \mathrm{M}$. For ATF4, the mRNA levels were slightly increased at $1.25 \mu \mathrm{M}$, and dramatically increased by 11.8 -fold in $\mathrm{HH}$ cells at 5.0 $\mu \mathrm{M}$. These results suggest that the effect of ONC201 on the down-regulation of JAK/STAT and NF- $\kappa \mathrm{B}$ pathways is not transcriptionally mediated. The slightly elevated mRNA levels may be a consequence of attenuation of protein translation that occurs with ISR activation.

\section{DISCUSSION}

We present pre-clinical data showing that ONC201 as a single agent demonstrated potent anti-cancer activity in CTCL cells by inhibiting cell proliferation and strongly inducing apoptosis in CTCL cell lines and primary lymphoma cells. The activity of ONC201 occurred in the low micromolar range, which is achievable in vivo based on prior animal experiments and results from the firstin-human trial $[7,31]$. Importantly, ONC201 was more effective in primary Sézary cells and SS-derived cell lines that are more aggressive and refractory, which consistent with prior published findings [7, 32] and highlights its potential clinical utility in advanced stage patients. Our study confirms that ONC201 works on CTCL cells also by activating ISR through inducing the expression of ATF4, inactivation of Akt, and induction of TRAIL, as previously reported in solid tumors. In addition, we are first to show that ONC201 can inactivate the JAK/STAT pathway as well as the NK-KB pathway in CTCL cells.

Clinical management of MF/SS starts with skin directed therapies, then addition of retinoid or interferon, targeted therapy, and radiation. Chemotherapy is used in the setting of transformed MF or nodal involvement. We previously reported that bexarotene and histone deacetylase inhibitors (HDACi), vorinostat and romidepsin, induce apoptosis of CTCL cells in vitro and are also active in CTCL patients [3, 33, 34]. Patients with advanced CTCL usually develop resistance to available treatments leading to disease progression and opportunistic infections [35]. Thus, more effective and less immunosuppressive anti-cancer agents are urgently needed for advanced CTCL patients.

In accordance with prior studies in other tumor types [36], ONC201 also induced the pro-apoptotic ligand TRAIL in CTCL cells, a critical effector mechanism in the immune surveillance of cancer. Vorinostat, a HDAC inhibitor approved for CTCL [34, 37], also upregulates transcription of TRAIL [38, 39]. It is promising that $\mathrm{ONC} 201$ induces the same pro-apoptotic ligand as a clinically approved agent in CTCL, although the mechanism of vorinostat-mediated TRAIL gene upregulation is distinct from that of ONC201 [40].

Previous studies suggest that ONC201 activates ISR by upregulating ATF4 [5, 8, 24, 41]. ATF4 has also been identified as a negative regulator of IRF7, which is mediated by direct binding interactions in addition to inhibition of the transcription and phosphorylation of IRF7 [28]. Activation of IRF7, a master regulator of interferon gene expression, triggers the induction of IFN $\alpha / \beta$, type I interferons, which binds to receptors to activate the JAK/STAT pathway [42]. Thus, ONC201mediated inactivation of the JAK/STAT pathway may be a consequence of ATF4 induction that can block IRF7 activation, resulting in decreased induction of interferons 


\section{A.}

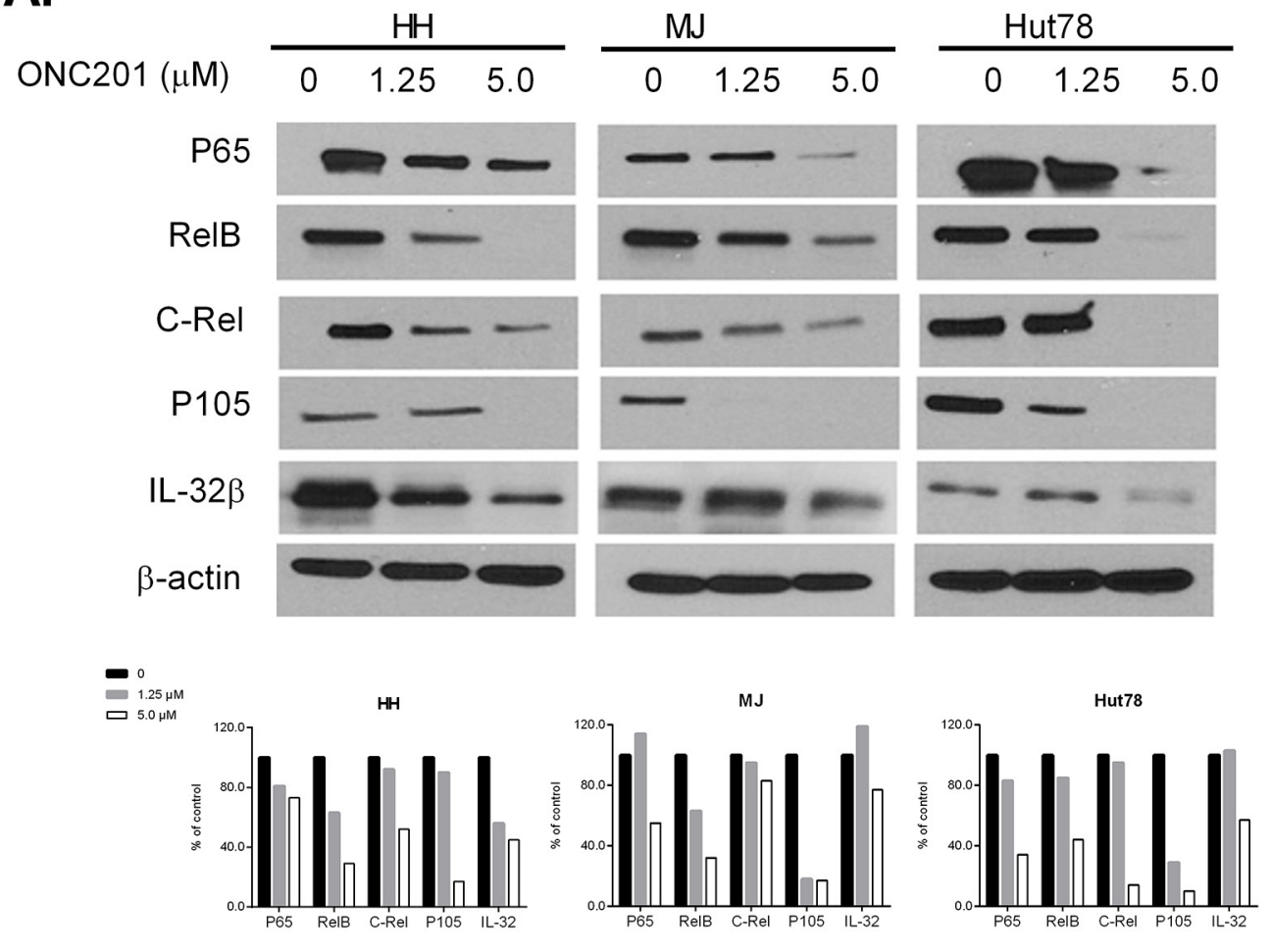

B.
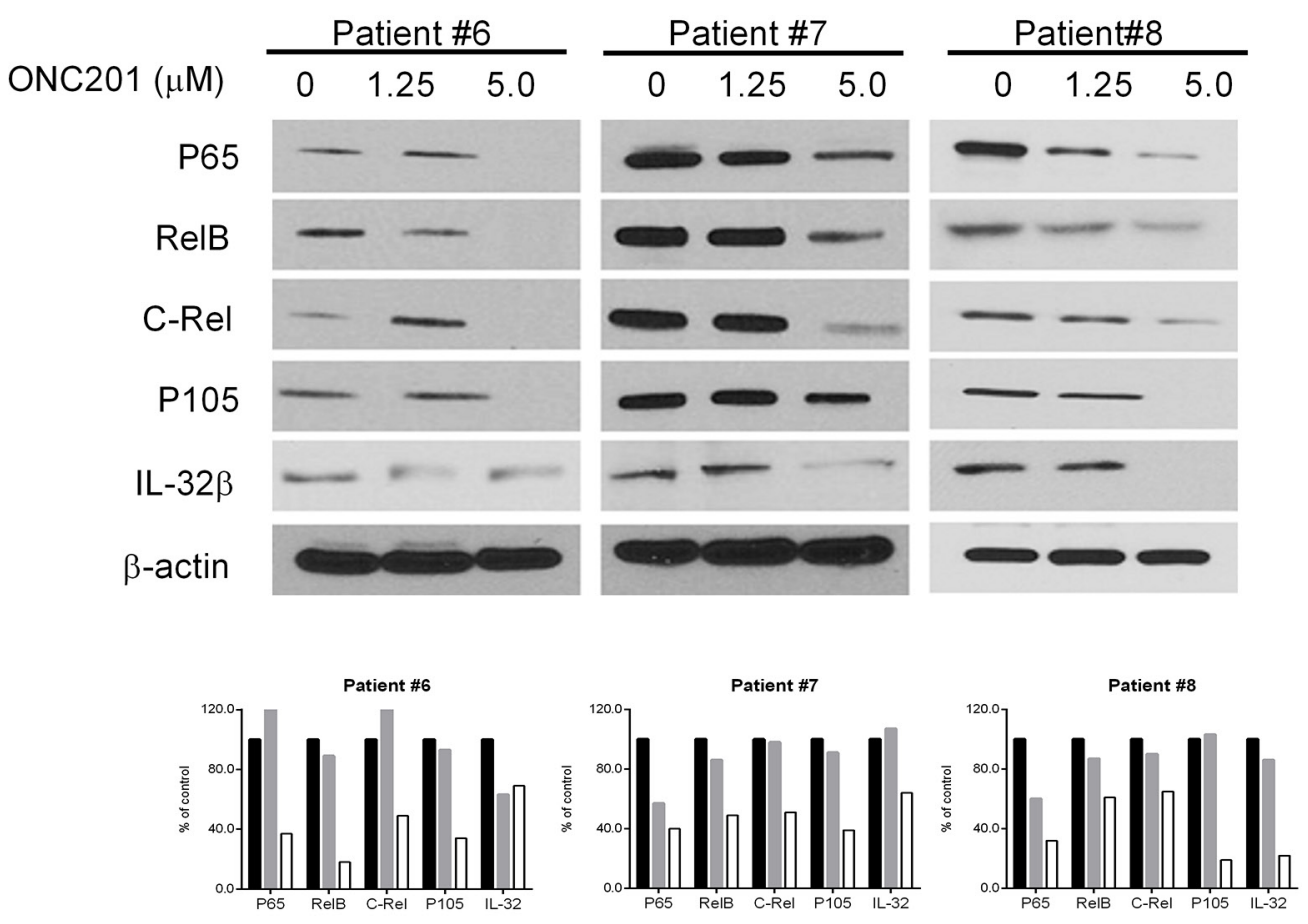

Figure 7: ONC201 downregulates NF-אB and IL-32 expression in CTCL cell lines and primary Sézary cells. HH, Hut78, and MJ cells (A), and PBMCs from $3 \mathrm{MF} / \mathrm{SS}$ patients (Patient \#6 - \#8) (B) were treated with (1.25 or $5.0 \mu \mathrm{M}$ ) or without ONC201 for $72 \mathrm{hrs.}$ The protein expression of NF-KB members and IL-32 $\beta$ were assessed by western blot. The protein level of $\beta$-actin served as housekeeping gene control. The protein levels were semi-quantified and the levels in treated cells were compared with untreated control cells which were considered as $100 \%$. 
and decreased subsequent activation of the JAK/STAT pathway. JAKs can phosphorylate tyrosines on receptors that ultimately stimulate the Ras signaling cascade, thereby activating Akt and ERK at a downstream level [42]. Prior studies with ONC201 in solid tumors have demonstrated a late stage inactivation of Akt and ERK, which results in less phosphorylated Foxo3a that can then enter the nucleus to upregulate TRAIL and other target genes. Thus, disruption of the JAK/STAT pathway by ONC201 may contribute to decreased activation of Akt and ERK as a late stage event of ONC201-induced signaling. However, the experiments to isolate the role of each target/pathway need be performed to understand the importance of each down-regulated pathway (NF- $\kappa \mathrm{B}$, JAK/STAT, and Akt) on anti-tumor effects by ONC201 on CTCL cells.

ISR activation often results in phosphorylation of eIF $2 \alpha$ and upregulation of certain transcription factors, such as ATF4. However, in this study, we only found an induction of ATF4 in ONC201-treated CTCL cells, but no induction of eIF $2 \alpha$ and p-eIF2 $\alpha$ proteins in ONC201-treated CTCL cells. In fact, while eIF2 $\alpha$-dependent ATF4 induction has been shown with ONC201 in several settings, there have been a few exceptions where we have seen eIF2-independent ATF4 upregulation [8]. Ishizawa et al found that ONC201 induced an atypical integrated stress response in mantle cell lymphoma and acute myeloid leukemia cells, and the increase of ATF4 in ONC201-treated hematopoietic cells promoted apoptosis and did not depend on increased phosphorylation of eIF2 $\alpha$ [8]. Thus, the induction of ATF4 in ONC201-treated CTCL cells may be independent of phosphorylation of eIF $2 \alpha$. Recent studies report that ONC201 also antagonizes the dopamine receptor D2 (DRD2)-like subfamily of G protein-coupled receptors (GPCRs) [43, 44]. DRD2 antagonism increases cyclic AMP and subsequently activates cAMP response element-binding protein (CREB). CREB has a positively regulating binding site on the ATF4 promoter [45]. Future studies on DRD2 and the cAMP signal pathway in ONC201-treated CTCL cells may help us disclose the mechanism(s) of action of ONC201 on CTCL.

The JAK/STAT pathway has been successfully targeted with small molecule inhibitors. Clinical trials are ongoing for Pacritinib and AZD9150 for the treatment of refractory colorectal cancer (NCT02277093) and hepatocellular carcinoma/non-Hodgkin's lymphoma (NCT01563302) [46]. In CTCL, preclinical studies have shown that the pharmacological inhibition of STAT3 promotes apoptosis [47, 48]. For example, the potent JAK/STAT3 inhibitor, cucurbitacin I, decreases STAT3 phosphorylation, resulting in apoptosis of Sézary cells $[49,50]$. Further studies in CTCL could explore the combinatorial efficacy of ONC201, which was recently revealed to be broadly synergistic [51].
In the past year, our group and others published findings of heterogeneous driver mutations and loss or gain of chromosomal regions using whole exome sequencing with or without RNA-seq that should ultimately advance our understanding of CTCLs [5254]. Loss of tumor suppressor genes is the most common findings, particularly loss of chromosome $10 \mathrm{q}$ region $[52,55,56]$, which encodes tumor suppressor genes such as PTEN, MXI1, and DMBT1, and loss of $17 \mathrm{p}$ region, encoding p53 and CRK [55]. Since mutations in p53 are among the most common mutations found in SS patients, ONC201 may be ideal for SS patients because its antitumor activity is independent of p53 [5].

ONC201 shows limited effects of anti-proliferation and apoptosis induction at 48 hours in treated CTCL cell lines, and the maximum activity was observed at 96 hours after single dose incubation. It is noticed that ONC201 has a short half-life, about 11 hours in humans [44], but its pharmacodynamics (PD) typically lasted several hours after single-dose administration that persists far beyond its pharmacokinetics (PK) [5]. This disconnect between $\mathrm{PK}$ and PD is now considering in designing combination therapy. ONC201 administered one to two days prior to another anti-cancer drug has demonstrated synergistic efficacy in preclinical models $[8,57]$.

In summary, ONC201 appears to be an active agent that impacts key signaling pathways in aggressive and refractory CTCL preclinical models through an apparently unique mechanism. The confirmation of robust activity in refractory patient samples is a good indicator that the anti-cancer activity of ONC201 will translate to the clinic. This notion is further supported by the fact that ONC201 modulates signaling pathways that have been successfully targeted in CTCL and other malignancies. ONC201 exhibits an uncommonly benign safety profile in preclinical settings and in early clinical trial experience. Advanced CTCL patients with limited tolerance for toxic regimens may be a suitable indication for ONC201 to offer therapeutic value. Another advantage of ONC201 is that it can be given as a pill taken once weekly. Along with the preclinical efficacy evidence and absence of toxicity, the coordinate disruption of key signaling pathways by ONC201 that are of highly significant relevance in the pathophysiology of CTCL warrants the clinical examination of ONC201 in advanced CTCL.

\section{MATERIALS AND METHODS}

\section{Reagents}

ONC201 was obtained from Oncoceutics, Inc. (Philadelphia, PA), dissolved in DMSO to a stock concentration of $20 \mathrm{mM}$, and stored at $-20^{\circ} \mathrm{C}$ for further use. Serial dilutions $(1.25,2.5,5.0$ and $10 \mu \mathrm{M})$ were made in RPMI-1640 Medium (Sigma-Aldrich, St Louis, MO) for this study. 


\section{Cells and cell culture}

Human CTCL cell lines derived from SS $(\mathrm{HH}$, Hut78) and MF (MJ) were purchased from ATCC (American Type Culture Collection, Rockville, MD). PB2S, H9, SeAx, MyLa, and Mac2A, were kindly provided by Dr. Ivan Litvinov (Department of Medicine, McGill University, Canada). The peripheral blood was collected from 6 healthy donors and from $8 \mathrm{MF} /$ SS patients who had high counts of blood $\mathrm{CD} 4^{+} \mathrm{CD} 26$ malignant T-cells (Table 1). Peripheral blood mononuclear cells (PBMCs) were isolated, and followed by $\mathrm{CD}^{+} \mathrm{T}$ cell selection using $\mathrm{CD}^{+} \mathrm{T}$ cell isolation kit (Miltenyi Biotec, San Diego, CA). The purity was analyzed by flow cytometry. This study was conducted according to the Declaration of Helsinki Principles. The study was approved by the institutional review board of the University of Texas MD Anderson Cancer Center. All CTCL cells were grown in RPMI-1640 Medium (SigmaAldrich, St. Louis, MO) supplemented with $10 \%$ heatinactivated FBS (Atlanta Biologicals, Norcross, GA), $2 \mathrm{mM}$ HEPES, and $1 \%$ penicillin-streptomycin in a humidified atmosphere with $5.0 \% \mathrm{CO}_{2}$ at $37^{\circ} \mathrm{C}$.

\section{Cell proliferation assay}

Cells were seeded in 96-well plates at a density of $5 \times 10^{4}$ cells/well in $200 \mu \mathrm{L}$ of complete medium, and incubated with $(1.25,2.5,5.0$ and $10 \mu \mathrm{M})$ or without ONC201 treatment for 48,72 , or $96 \mathrm{hrs,} \mathrm{respectively.} \mathrm{The}$ cell viability was then determined using the CellTiter 96 Aqueous One Solution Cell Proliferation Assay (MTS) (Promega, Madison, WI) as previously described [33]. Absorbance was measured at $490 \mathrm{~nm}$ using the $\mu$ Quant plate reader (Biotek, Winooski, VT). Experiments were performed in triplicate.

\section{Apoptosis analysis by flow cytometry}

Cells were incubated at $5 \times 10^{5}$ cells $/ \mathrm{mL}$ with $(1.25$, $2.5,5.0$, and $10 \mu \mathrm{M})$ or without ONC201 treatment for 48, 72 or $96 \mathrm{hrs}$, and then harvested. The apoptotic cells were analyzed by flow cytometry using the Annexin V-FITC Detection Kit I (BD Pharmingen, San Diego, CA) as previously described [33].

\section{Cell cycle analysis by flow cytometry}

Cells were incubated at $5 \times 10^{5}$ cells $/ \mathrm{mL}$ with 1.25 , $2.5,5.0$, and $10 \mu \mathrm{M}$ or without ONC201 treatment for 48, 72 or $96 \mathrm{hrs}$, and then harvested. After washing with cold phosphate-buffered saline (PBS), cells were fixed in cold $100 \%$ ethanol and stored at $-20^{\circ} \mathrm{C}$ for 1 hour. They were then treated with DNase-free RNase (Roche Diagnostics, Basel, Switzerland) and stained with $50 \mu \mathrm{g}$ per $\mathrm{mL}$ of propidium iodide (PI) (Sigma-Aldrich, St. Louis, MO). Distribution of cell cycle phases by varying DNA content was determined with a FACSCalibur flow cytometer (Becton Dickinson). Analyses of cell cycle distribution, including of sub-G1 populations, were performed as previously described [33].

\section{Western blot and semi-quantification analysis}

The cellular proteins (5 or $10 \mu \mathrm{g}$ ) extracted from treated cells were subjected to $4-20 \%$ Mini-Protean TGX gel (Bio-Rad, Hercules, CA) electrophoresis and transferred onto nitrocellulose membranes (Whatman GmbH, Dassel, Germany). The membranes were blocked in $5.0 \%$ milk in TBST $(50 \mathrm{mM}$ Tris $\mathrm{pH} 7.5,150 \mathrm{mM}$ $\mathrm{NaCl}, 0.05 \%$ Tween 20 ) for 1 hour at room temperature, then incubated with primary antibodies overnight at $4{ }^{\circ} \mathrm{C}$ in $5.0 \%$ milk in TBST. Then membranes were incubated with 1:2,000 peroxidase-conjugated anti-mouse or antirabbit secondary antibodies (Cell Signaling, Beverly, MA) for 1 hour at room temperature. The primary antibodies and dilutions used in this study were listed as follows: eIF2 $\alpha$ 1:1000, p-eIF2 1:1000, ATF4 1:2000, AKT 1:2000, TRAIL1:2000, BAX1:2000, cleaved-PARP 1:2000, JAK3 1:1000, pJAK3 1:1000, STAT3 1:2000, pSTAT13 1:2000, pSTAT1 1:2000, IRF7 1:2000, p-IRF7 1:1000, NF-кB p65 1:2000, RelB 1:1000, c-Rel 1:1000, IL-32 $\beta$ 1:1000, $\beta$-Actin 1:5000 (Cell Signaling, Beverly, MA). Protein bands were visualized using the Super Signal West Pico Chemiluminescence Substrate kit (Thermo, Rockford, IL). Equivalent loading of proteins in each well was confirmed by $\beta$-actin and Ponceau staining. For semi-quantification of protein expression, target bands were scanned. Then, scanned images were converted to 8-bit format images using ImageJ software (NIH). Density of each band was used for further calculation. The levels of each protein in treated cells were compared with untreated control cells which were considered as $100 \%$ [26].

\section{Quantitative real-time PCR for mRNA expression}

Total RNA was extracted by RNeasy Mini kit (Qiagen, Valencia, CA) from HH, MJ, and Hut78 cells with ONC201 treatment at $0,1.25 \mu \mathrm{M}$, and $5.0 \mu \mathrm{M}$ for 48 hours and 72 hours. First strand cDNA was synthesized from $1000 \mathrm{ng}$ of total RNA with an oligo (dT) 12-18 primer using Superscript IV reverse transcriptase (Life Technologies Inc., Gaithersburg, MD). Pre-formulated TaqMan primers and probes for eIF2S1 (Hs00187953 m1), ATF4 (Hs00909569_m1), Akt1 (Hs00178289_m1), BAX (Hs00180269_m1), JAK3 (Hs00354555_m1), STAT1 (Hs01013996_m1), STAT3 (Hs00374280_m1), IRF7 (Hs01014809_m1), NFKB1 (Hs00765730_m1), IL-32(Hs00992441_m1), were used. Glyceraldehye-3phosphate dehydrogenase (GAPDH, Hs02786624-g1) was used as endogenous control gene. Quantitative PCR was run in the ABI Prism 7000 Sequence Detection System using the default protocol by the manufacturer (Applied 
Biosystems, Foster City, CA). The relative levels of mRNA expression were quantitated based on the $\mathrm{Ct}$ value and then normalized to GAPDH. Relative fold changes were finally calculated [58].

\section{Statistical analysis}

The differences in cell viability, apoptosis, and sub-G1 of cell cycle in ONC201 treated cells were compared with the untreated cells or vehicle controls. Statistical significance was determined by Student's or paired t-test. The minimum level of significance was $\mathrm{p}<0.05$. Experiments were repeated twice and carried out in triplicate.

\section{Abbreviations}

GPCR: $\mathrm{G}$ protein-coupled receptor; DRD2:dopamine receptor D2; CREB: cAMP response element-binding protein; eIF $2 \alpha$ : eukaryotic initiation factor $2 \alpha$; ATF4: activating transcription factor 4; TRAIL: TNF-related apoptosis-inducing ligand; DR5: death receptor 5; TNF: tumor necrosis family; IRF7: interferon regulatory factor 7; CTCL: cutaneous T-cell lymphoma

\section{Author contributions}

X.N. contributed to project design, execution, supervision, data interpretation, manuscript writing, revising, and finalizing. X.Z. conducted most experiments including cell growth, apoptosis, and protein expression assessment. He also helped with data analysis and figure preparation. C.H helped with mRNA expression assays and assessment of eIF $2 \alpha$ expression. T.L. helped with cell culture, patient sample preparation, and flow cytometry analysis. J.E.A., W.O., and M.D., conceived the project. R.S.T. contributed to the initiation of the project. J.E.A and M.D. also contributed to manuscript preparation and revision.

\section{ACKNOWLEDGMENTS}

Authors thank Daniel Lewis, a medical student from Baylor School of Medicine, for manuscript proofreading. We also thank our patients who participated in this study.

\section{CONFLICTS OF INTEREST}

R.S.T., J.E.A. and W.O. are employees and shareholders of Oncoceutics.

\section{FUNDING}

Drs. Martin and Dorothy Spatz Foundation (M.D., X.N.) and Oncoceutics, Inc. (J.E.A., R.S.T., W.O., and
M.D.) support the research. The study was also supported in part by the Blanche Bender Professorship in Cancer Research (M.D.).

\section{REFERENCES}

1. Wong HK. Novel biomarkers, dysregulated epigenetics, and therapy in cutaneous T-cell lymphoma. Discov Med. 2013; 16:71-78

2. Duvic M, Foss FM. Mycosis fungoides: pathophysiology and emerging therapies. Semin Oncol. 2007; 34:S21-28.

3. Foss F, Duvic M, Lerner A, Waksman J, Whittaker S. Clinical efficacy of romidepsin in tumor stage and folliculotropic mycosis fungoides. Clin Lymphoma Myeloma Leuk. 2016; 16:637-643.

4. Scarisbrick JJ, Prince HM, Vermeer MH, Quaglino P, Horwitz S, Porcu P, Stadler R, Wood GS, Beylot-Barry M, Pham-Ledard A, Foss F, Girardi M, Bagot M, et al. Cutaneous lymphoma international consortium study of outcome in advanced stages of mycosis fungoides and sezary syndrome: effect of specific prognostic markers on survival and development of a prognostic model. J Clin Oncol. 2015; 33:3766-3773.

5. Allen JE, Kline CL, Prabhu VV, Wagner J, Ishizawa J, Madhukar N, Lev A, Baumeister M, Zhou L, Lulla A, Stogniew M, Schalop L, Benes C, et al. Discovery and clinical introduction of first-in-class imipridone ONC201. Oncotarget. 2016; 7:74380-74392. doi: 10.18632/ oncotarget. 11814.

6. Wagner J, Kline CL, Pottorf RS, Nallaganchu BR, Olson GL, Dicker DT, Allen JE, El-Deiry WS. The angular structure of ONC201, a TRAIL pathway-inducing compound, determines its potent anti-cancer activity. Oncotarget. 2014; 5:12728-12737. doi: 10.18632/ oncotarget.2890.

7. Allen JE, Krigsfeld G, Mayes PA, Patel L, Dicker DT, Patel AS, Dolloff NG, Messaris E, Scata KA, Wang W, Zhou JY, Wu GS, El-Deiry WS. Dual inactivation of Akt and ERK by TIC10 signals Foxo3a nuclear translocation, TRAIL gene induction, and potent antitumor effects. Sci Transl Med. 2013; 5:171ra117.

8. Ishizawa J, Kojima K, Chachad D, Ruvolo P, Ruvolo V, Jacamo RO, Borthakur G, Mu H, Zeng Z, Tabe Y, Allen JE, Wang Z, Ma W, et al. ATF4 induction through an atypical integrated stress response to ONC201 triggers p53-independent apoptosis in hematological malignancies. Sci Signal. 2016; 9:ra17.

9. Netchiporouk E, Litvinov IV, Moreau L, Gilbert M, Sasseville D, Duvic M. Deregulation in STAT signaling is important for cutaneous T-cell lymphoma (CTCL) pathogenesis and cancer progression. Cell Cycle. 2014; 13:3331-3335.

10. Litvinov IV, Pehr K, Sasseville D. Connecting the dots in cutaneous $\mathrm{T}$ cell lymphoma (CTCL): STAT5 regulates 
malignant $\mathrm{T}$ cell proliferation via miR-155. Cell Cycle. 2013; 12:2172-2173.

11. Kopp KL, Ralfkiaer U, Gjerdrum LM, Helvad R, Pedersen IH, Litman T, Jonson L, Hagedorn PH, Krejsgaard T, Gniadecki R, Bonefeld CM, Skov L, Geisler C, et al. STAT5-mediated expression of oncogenic miR155 in cutaneous T-cell lymphoma. Cell Cycle. 2013; 12:1939-1947.

12. Brender C, Lovato P, Sommer VH, Woetmann A, Mathiesen AM, Geisler C, Wasik M, Odum N. Constitutive SOCS-3 expression protects T-cell lymphoma against growth inhibition by IFNalpha. Leukemia. 2005; 19:209-213.

13. Qin JZ, Zhang CL, Kamarashev J, Dummer R, Burg G, Dobbeling U. Interleukin-7 and interleukin-15 regulate the expression of the bcl-2 and c-myb genes in cutaneous T-cell lymphoma cells. Blood. 2001; 98:2778-2783.

14. Zhang Q, Wang HY, Woetmann A, Raghunath PN, Odum $\mathrm{N}$, Wasik MA. STAT3 induces transcription of the DNA methyltransferase 1 gene (DNMT1) in malignant $\mathrm{T}$ lymphocytes. Blood. 2006; 108:1058-1064.

15. DiDonato JA, Mercurio F, Karin M. NF-kappaB and the link between inflammation and cancer. Immunol Rev. 2012; 246:379-400.

16. O’Connell MA, Cleere R, Long A, O’Neill LA, Kelleher D. Cellular proliferation and activation of NF kappa B are induced by autocrine production of tumor necrosis factor alpha in the human T lymphoma line HuT 78. J Biol Chem. 1995; 270:7399-7404.

17. Cleere R, Long A, Kelleher D, O’Neill LA. Autocrine regulation of the transcription factor NF kappa B by TNF alpha in the human T cell lymphoma line Hut 78. Biochem Soc Trans. 1995; 23:113S.

18. Wismer JM, McKenzie RC, Sauder DN. Interleukin-8 immunoreactivity in epidermis of cutaneous T-cell lymphoma patients. Lymphokine Cytokine Res. 1994; 13:21-27.

19. Tron VA, Rosenthal D, Sauder DN. Epidermal interleukin-1 is increased in cutaneous T-cell lymphoma. J Invest Dermatol. 1988; 90:378-381.

20. Krejsgaard T, Ralfkiaer U, Clasen-Linde E, Eriksen KW, Kopp KL, Bonefeld CM, Geisler C, Dabelsteen S, Wasik MA, Ralfkiaer E, Woetmann A, Odum N. Malignant cutaneous T-cell lymphoma cells express IL-17 utilizing the Jak3/Stat3 signaling pathway. J Invest Dermatol. 2011; 131:1331-1338.

21. Chong BF, Wilson AJ, Gibson HM, Hafner MS, Luo Y, Hedgcock CJ, Wong HK. Immune function abnormalities in peripheral blood mononuclear cell cytokine expression differentiates stages of cutaneous T-cell lymphoma/mycosis fungoides. Clin Cancer Res. 2008; 14:646-653.

22. Juvekar A, Manna S, Ramaswami S, Chang TP, Vu HY, Ghosh CC, Celiker MY, Vancurova I. Bortezomib induces nuclear translocation of IkappaBalpha resulting in genespecific suppression of NF-kappaB--dependent transcription and induction of apoptosis in CTCL. Mol Cancer Res. 2011; 9:183-194.

23. Grivennikov SI, Karin M. Dangerous liaisons: STAT3 and NF-kappaB collaboration and crosstalk in cancer. Cytokine Growth Factor Rev. 2010; 21:11-19.

24. Kline CL, Van den Heuvel AP, Allen JE, Prabhu VV, Dicker DT, El-Deiry WS. ONC201 kills solid tumor cells by triggering an integrated stress response dependent on ATF4 activation by specific eIF2 $\alpha$ kinases. Sci Signal. 2016; 9:ra18.

25. Galimberti V, Kinor N, Shav-Tal Y, Biggiogera M, Bruning A. The stress-inducible transcription factor ATF4 accumulates at specific rRNA-processing nucleolar regions after proteasome inhibition. Eur J Cell Biol. 2016; 95:389-400.

26. Zhang C, Li B, Zhang X, Hazarika P, Aggarwal BB, Duvic M. Curcumin selectively induces apoptosis in cutaneous T-cell lymphoma cell lines and patients' PBMCs: potential role for STAT-3 and NF-kappaB signaling. J Invest Dermatol. 2010; 130:2110-2119.

27. Hira SK, Mondal I, Bhattacharya D, Manna PP. Downregulation of endogenous STAT3 augments tumoricidal activity of interleukin 15 activated dendritic cell against lymphoma and leukemia via TRAIL. Exp Cell Res. 2014; 327:192-208.

28. Liang Q, Deng H, Sun CW, Townes TM, Zhu F. Negative regulation of IRF7 activation by activating transcription factor 4 suggests a cross-regulation between the IFN responses and the cellular integrated stress responses. J Immunol. 2011; 186:1001-1010.

29. Suga H, Sugaya M, Miyagaki T, Kawaguchi M, Fujita H, Asano Y, Tada Y, Kadono T, Sato S. The role of IL-32 in cutaneous T-cell lymphoma. J Invest Dermatol. 2014; 134:1428-1435.

30. Wang L, Ni X, Covington KR, Yang BY, Shiu J, Zhang X, Xi L, Meng Q, Langridge T, Drummond J. Genomic profiling of Sezary syndrome identifies alterations of key $\mathrm{T}$ cell signaling and differentiation genes. Nat Genet. 2015; 47:1426-1434.

31. Stein MN, Mayer TM, Moss RA, Silk AW, Chan N, Haffty BG, DiPaola RS, Beckett Y, Bentlyewski E, Zheng L, Fang B, Allen J, Mehnert JM. First-in-human dose escalation study of oral ONC201 in advanced solid tumors. J Clin Oncol. 2015.

32. Prabhu VV, Allen JE, Dicker DT, El-Deiry WS. Small molecule ONC201/TIC10 targets chemotherapy-resistant colorectal cancer stem-like cells in an Akt/Foxo3a/TRAILdependent manner. Cancer Res. 2015; 75:1423-1432.

33. Zhang C, Richon V, Ni X, Talpur R, Duvic M. Selective induction of apoptosis by histone deacetylase inhibitor SAHA in cutaneous T-cell lymphoma cells: relevance to mechanism of therapeutic action. J Invest Dermatol. 2005; 125:1045-1052. 
34. Duvic M, Talpur R, Ni X, Zhang C, Hazarika P, Kelly C, Chiao JH, Reilly JF, Ricker JL, Richon VM, Frankel SR. Phase 2 trial of oral vorinostat (suberoylanilide hydroxamic acid, SAHA) for refractory cutaneous T-cell lymphoma (CTCL). Blood. 2007; 109:31-39.

35. Piekarz RL, Robey RW, Zhan Z, Kayastha G, Sayah A, Abdeldaim AH, Torrico S, Bates SE. T-cell lymphoma as a model for the use of histone deacetylase inhibitors in cancer therapy: impact of depsipeptide on molecular markers, therapeutic targets, and mechanisms of resistance. Blood. 2004; 103:4636-4643.

36. Falschlehner C, Schaefer U, Walczak H. Following TRAIL's path in the immune system. Immunology. 2009; 127:145-154.

37. Olsen EA, Duvic M, Breneman D, Pacheco TR, Parker S, Vonderheid EC, Ricker JL, Rizvi S, Boileau K, Geskin LJ. Vorinostat provides prolonged safety and clinical benefit to patients with advanced cutaneous t-cell lymphoma (CTCL). J Clin Oncol. 2008; 26:14588.

38. Mann BS, Johnson JR, Cohen MH, Justice R, Pazdur R. FDA approval summary: vorinostat for treatment of advanced primary cutaneous T-cell lymphoma. Oncologist. 2007; 12:1247-1252.

39. Nebbioso A, Clarke N, Voltz E, Germain E, Ambrosino C, Bontempo P, Alvarez R, Schiavone EM, Ferrara F, Bresciani F, Weisz A, de Lera AR, Gronemeyer H, Altucci L. Tumor-selective action of HDAC inhibitors involves TRAIL induction in acute myeloid leukemia cells. Nat Med. 2005; 11:77-84.

40. Allen JE, El-Deiry WS. Regulation of the human TRAIL gene. Cancer Biol Ther. 2012; 13:1143-1151.

41. Ishizawa J, Kojima K, Chachad D, Ruvolo PP, Ruvolo VR, Jacamo R, Dilip A, Mu H, Zeng Z, Matre P, Allen JE, Neelapu SS, McDonnell TJ, et al. ONC201 induces p53independent apoptosis and cell cycle arrest in hematological malignancies and leukemic stem/progenitor cells by inducing ER stress and mTOR inhibition. Blood. 2014; 124:3122.

42. Darnell JE Jr, Kerr IM, Stark GR. Jak-STAT pathways and transcriptional activation in response to IFNs and other extracellular signaling proteins. Science. 1994; 264:1415-1421.

43. Madhukar NS, Elemento O, Benes CH, Garnett MJ, Stein M, Bertino JR, Kaufman HL, Arrillaga-Romany I, Batchelor TT, Schalop L, Oster W, Stogniew M, Andreeff M, et al. Abstract LB-209: D2-like dopamine receptor antagonism by ONC201 identified by confluence of computational, receptor binding, and clinical studies. Cancer Res. 2016; 76:LB-209-LB-209.

44. Stein MN, Bertino JR, Kaufman HL, Mayer T, Moss R, Silk A, Chan N, Malhotra J, Rodriguez-Rodriguez L, Aisner J, Aiken RD, Haffty BG, DiPaola RS, et al. First-in-human clinical trial of oral ONC201 in patients with refractory solid tumors. Clin Cancer Res. 2017.
45. Song H, Luo J, Luo W, Weng J, Wang Z, Li B, Li D, Liu M. Inactivation of G-protein-coupled receptor 48 (Gpr48/ Lgr4) impairs definitive erythropoiesis at midgestation through down-regulation of the ATF4 signaling pathway. J Biol Chem. 2008; 283:36687-36697.

46. Furqan M, Akinleye A, Mukhi N, Mittal V, Chen Y, Liu D. STAT inhibitors for cancer therapy. J Hematol Oncol. 2013; 6:90.

47. Nielsen M, Kaestel CG, Eriksen KW, Woetmann A, Stokkedal T, Kaltoft K, Geisler C, Ropke C, Odum N. Inhibition of constitutively activated Stat 3 correlates with altered Bcl-2/Bax expression and induction of apoptosis in mycosis fungoides tumor cells. Leukemia. 1999; 13:735-738.

48. Nielsen M, Kaltoft K, Nordahl M, Ropke C, Geisler C, Mustelin T, Dobson P, Svejgaard A, Odum N. Constitutive activation of a slowly migrating isoform of Stat 3 in mycosis fungoides: tyrphostin AG490 inhibits Stat3 activation and growth of mycosis fungoides tumor cell lines. Proc Natl Acad Sci U S A. 1997; 94:6764-6769.

49. van Kester MS, Out-Luiting JJ, von dem Borne PA, Willemze R, Tensen CP, Vermeer MH. Cucurbitacin I inhibits Stat 3 and induces apoptosis in Sezary cells. J Invest Dermatol. 2008; 128:1691-1695.

50. Blaskovich MA, Sun J, Cantor A, Turkson J, Jove R, Sebti SM. Discovery of JSI-124 (cucurbitacin I), a selective Janus kinase/signal transducer and activator of transcription 3 signaling pathway inhibitor with potent antitumor activity against human and murine cancer cells in mice. Cancer Res. 2003; 63:1270-1279.

51. Allen JE, Prabhu VV, Talekar M, van den Heuvel P, Lim B, Dicker DT, Fritz JL, Beck A, El-Deiry WS. Genetic and pharmacological screens converge in identifying FLIP, BCL2 and IAP proteins as key regulators of sensitivity to the TRAIL-inducing anti-cancer agent ONC201/TIC10. Cancer Res. 2015; 75:1668-1674.

52. Wang L, Ni X, Covington KR, Yang BY, Shiu J, Zhang X, Xi L, Meng Q, Langridge T, Drummond J, Donehower LA, Doddapaneni H, Muzny DM, et al. Genomic profiling of Sezary syndrome identifies alterations of key $\mathrm{T}$ cell signaling and differentiation genes. Nat Genet. 2015; 47:1426-1434.

53. Choi J, Goh G. Genomic landscape of cutaneous T cell lymphoma. Nat Genet. 2015; 47:1011-1019.

54. Ungewickell A, Bhaduri A, Rios E, Reuter J, Lee CS, Mah A, Zehnder A, Ohgami R, Kulkarni S. Genomic analysis of mycosis fungoides and Sezary syndrome identifies recurrent alterations in TNFR2. Nat Genet. 2015; 47:1056-1060.

55. Fischer TC, Gellrich S, Muche JM, Sherev T, Audring H, Neitzel H, Walden P, Sterry W, Tonnies H. Genomic aberrations and survival in cutaneous T cell lymphomas. J Invest Dermatol. 2004; 122:579-586.

56. Thangavelu M, Finn WG, Yelavarthi KK, Roenigk HH Jr, Samuelson E, Peterson L, Kuzel TM, Rosen ST. Recurring structural chromosome abnormalities in peripheral blood 
lymphocytes of patients with mycosis fungoides/Sezary syndrome. Blood. 1997; 89:3371-3377.

57. Karpel-Massler G, Ba M, Shu C, Halatsch ME, Westhoff MA, Bruce JN, Canoll P, Siegelin MD. TIC10/ONC201 synergizes with $\mathrm{Bcl}-2 / \mathrm{Bcl}-\mathrm{xL}$ inhibition in glioblastoma by suppression of Mcl-1 and its binding partners in vitro and in vivo. Oncotarget. 2015; 6:36456-36471. doi: 10.18632/ oncotarget.5505.
58. Ni X, Jorgensen JL, Goswami M, Challagundla P, Decker WK, Kim YH, Duvic MA. Reduction of regulatory T cells by Mogamulizumab, a defucosylated anti-CC chemokine receptor 4 antibody, in patients with aggressive/refractory mycosis fungoides and Sezary syndrome. Clin Cancer Res. 2015; 21:274-285. 